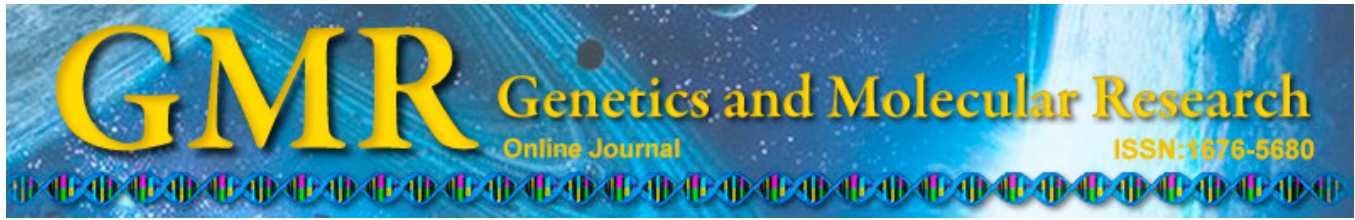

\title{
Association between angiogenic growth factor genetic polymorphisms and the risk of osteosarcoma
}

\author{
H.F. Zhang, J.P. Yan, Y.S. Zhuang and G.Q. Han \\ Department of Orthopedics, Affiliated Hospital of Weifang Medical University, \\ Shandong, China \\ Corresponding author: H.F. Zhang \\ E-mail: zhanghf92@163.com
}

Genet. Mol. Res. 14 (3): 10524-10529 (2015)

Received February 5, 2015

Accepted May 18, 2015

Published September 8, 2015

DOI http://dx.doi.org/10.4238/2015.September.8.14

ABSTRACT. The aim of this study was to assess the role of the $V E G F-2578 \mathrm{C} / \mathrm{A},+936 \mathrm{C} / \mathrm{T}$, and $-460 \mathrm{~T} / \mathrm{C}$ gene polymorphisms in the development of osteosarcoma. A total of 182 patients with osteosarcoma and 182 age- and gender-matched healthy controls were enrolled into our study during January 2011 and December 2013. Genotype frequencies of the $V E G F-2578 \mathrm{C} / \mathrm{A}$ and $-460 \mathrm{~T} / \mathrm{C}$ alleles in controls were found to be within the parameters of Hardy-Weinberg equilibrium, but the genotype frequencies of $+936 \mathrm{C} / \mathrm{T}$ alleles were not. By conditional regression analysis, we detected a statistically significantly increased risk of osteosarcoma in patients with the AA genotype $(\mathrm{OR}=1.97 ; 95 \% \mathrm{CI}=1.02-3.83)$ and the $\mathrm{CA}+\mathrm{AA}$ genotype $(\mathrm{OR}=1.57 ; 95 \% \mathrm{CI}=1.01-2.44)$ of $-2578 \mathrm{C} / \mathrm{A}$ when compared with $\mathrm{CC}$ genotype. Therefore, our study showed that the AA and CA+AA genotypes of the $V E G F-2578 \mathrm{C} / \mathrm{A}$ polymorphism might modify the risk of osteosarcoma in a Chinese population.

Key words: VEGF; Polymorphisms; Osteosarcoma 


\section{INTRODUCTION}

Osteosarcoma is derived from mesenchymal tissues, and often occurs in the long bones of the body such as the distal femur, proximal tibia, and humeral metaphysis. Osteosarcoma is most common in children and adolescents, with an annual incidence of approximately 3/1,000,000 (Picci, 2007; Mirabello et al., 2009; Ottaviani and Jaffe, 2009). It is well known that the development of osteosarcoma involves a complex, multistep, and multifactorial process (de Alava, 2007; Bovée and Hogendoorn, 2010; Powers et al., 2010). Several studies have investigated the role of cancer stem cells in osteosarcoma and their potential to cause tumors (Berger et al., 2008; Osuna and de Alava, 2009), the results of which suggested that genetic factors play an important role in the development of osteosarcoma (Jia et al., 2013; He et al., 2013, 2014).

Angiogenesis, the formation of new blood vessels from preexisting endothelium, is a discrete event in carcinogenesis that is related to the aggressive potential of a tumor (Hanahan and Folkman, 1996; Nakamura et al., 2005). Accumulating evidence suggests that the growth of tumors is associated with increased angiogenesis and that the formation of new blood vessels is a fundamental step in tumor development and expansion (Mariani et al., 2012). Vascular endothelial growth factor (VEGF) is a potent angiogenic growth factor, and the polymorphisms in $V E G F$ have been shown to influence the expression of this gene through altering the initiation of transcription and the internal initiation of translation (Akiri et al., 1998). Several single nucleotide polymorphisms (SNPs) in the 5'- and 3'-untranslated region have been reported to be associated with alteration of VEGF protein production, including $-2578 \mathrm{C} / \mathrm{A},+936 \mathrm{C} / \mathrm{T}$, and $-460 \mathrm{~T} / \mathrm{C}$.

Several previous studies have assessed the association between gene polymorphisms in VEGF and cancer risk, but the results have been inconsistent (Chen et al., 2014; Kapahi et al., 2014; Yang et al., 2014; Rinck-Junior et al., 2015). However, only two studies have reported the association of $V E G F$ gene variations with the risk of osteosarcoma (Tie et al., 2014; Wang et al., 2014). The aim of this study was to assess the role of the $V E G F-2578 \mathrm{C} / \mathrm{A}$, $+936 \mathrm{C} / \mathrm{T}$, and $-460 \mathrm{~T} / \mathrm{C}$ gene polymorphisms in the development of osteosarcoma.

\section{MATERIAL AND METHODS}

\section{Study population}

A hospital-based case-control study was conducted in our study. A total of 182 patients with osteosarcoma and 182 age- and gender-matched healthy controls were enrolled during January 2011 and December 2013 in the Affiliated Hospital of Weifang Medical University. The patients with osteosarcoma were newly diagnosed and histopathologically confirmed independently by two pathologists. For patients, clinical and pathological information was extracted from the medical records, including gender, age, tumor stage and location, tumor metastasis, and family history of cancer. The control subjects were collected from among individuals who sought routine health examinations in our hospital. The control subjects were confirmed to be without osteosarcoma and to have no medical history of any cancer, and no family history of osteosarcoma in first-degree relatives.

The Ethics Committee of the Affiliated Hospital of Weifang Medical University approved the study protocols, and all participants provided written informed consent according to the Declaration of Helsinki. 


\section{DNA extraction and genotyping}

The commercially available TIANamp Blood DNA Kit (Tiangen Inc., Beijing, China) was used to extract DNA from peripheral blood leukocytes obtained from the study subjects. The polymerase chain reaction-restriction fragment length polymorphism (PCR-RFLP) assay was applied to assess the $V E G F-2578 \mathrm{C} / \mathrm{A},+936 \mathrm{C} / \mathrm{T}$, and $-460 \mathrm{~T} / \mathrm{C}$ gene polymorphisms. The PCR primers for each polymorphism were designed by the Sequenom Assay Design 3.1 software (San Diego, CA, USA). The forward and reverse primers for $V E G F-2578 \mathrm{C} / \mathrm{A}$ were 5'-GGATGGGGCTGACTAGGTAAGC-3' and 5'-AGCCCCCTTTTCCTCCAAC-3', respectively. The primers for VEGF +936C/T were 5'-CTCGGTGATTTAGCAGCAAG-3' and 5'-CTCGGTGATTTAGCAGCAAG-3', respectively. The primers for VEGF -460T/C were 5'-GGAGCGAGCAGCGTCTT-3' and 5'-GGACAGGCGAGCCTCAG-3', respectively. PCRs were carried out in a Perkin-Elmer 9700 thermocycler (Waltham, MA, USA) with an initial denaturation step of $8 \mathrm{~min}$ at $94^{\circ} \mathrm{C}$, followed by 30 cycles at $94^{\circ} \mathrm{C}$ for $30 \mathrm{~s}$, annealing at $60^{\circ} \mathrm{C}$ for $30 \mathrm{~s}$, and extension at $72^{\circ} \mathrm{C}$ for $1 \mathrm{~min}$. The resulting DNA fragments were electrophoresed on a $3.5 \%$ agarose gel and visualized under UV light after ethidium bromide staining.

\section{Statistical analysis}

The SPSS version 16.0 statistical software (SPSS Inc., Chicago, IL, USA) was used for statistical analysis. Differences between continuous variables were assessed by the Student $t$-test, while those between categorical variables were evaluated using the Pearson $\chi^{2}$ test. HardyWeinberg equilibrium of $V E G F-2578 \mathrm{C} / \mathrm{A},+936 \mathrm{C} / \mathrm{T}$, and $-460 \mathrm{~T} / \mathrm{C}$ genotype frequencies in the controls was tested using a goodness-of-fit $\chi^{2}$ test. The existence of differences in genotypic frequencies between groups was assessed by means of the Pearson $\chi^{2}$ test and by calculating the ORs with $95 \%$ CIs. A P value was considered to be significant at a level of $<0.05$.

\section{RESULTS}

The characteristics of patients with osteosarcoma and controls are shown in Table 1. No statistically significant differences were found between patients and controls in terms of age $(\mathrm{P}=0.67)$, gender $(\mathrm{P}=1.0)$, or family history of cancer $(\mathrm{P}=0.42)$. The mean ages were $20.6 \pm 11.6$ years for patients and $21.4 \pm 12.1$ years for controls. We also found that $68.68 \%$ of tumors were located on long tubular bones, and the majority of the others were located on the axial skeleton $(31.32 \%)$. In the patient group, $34.62 \%$ of tumors showed tumor metastasis and the others did not $(65.38 \%)$.

The genotype frequencies of $V E G F-2578 \mathrm{C} / \mathrm{A}$ and $-460 \mathrm{~T} / \mathrm{C}$ polymorphisms in the controls were within the parameters of Hardy-Weinberg equilibrium, but the genotype frequencies of $+936 \mathrm{C} / \mathrm{T}$ were not (Table 2). The minor allele frequencies (MAFs) of the $V E G F$ $-2578 \mathrm{C} / \mathrm{A},+936 \mathrm{C} / \mathrm{T}$, and $-460 \mathrm{~T} / \mathrm{C}$ variants in the controls were similar to those in the general Chinese population, as described in the National Center for Biotechnology Information (NCBI) dbSNP database. The MAFs of the three SNPs were over $10 \%$.

By conditional regression analysis, we detected a statistically significantly increased risk of osteosarcoma in patients with the AA genotype $(\mathrm{OR}=1.97 ; 95 \% \mathrm{CI}=1.02-3.83)$ and the $\mathrm{CA}+\mathrm{AA}$ genotype $(\mathrm{OR}=1.57 ; 95 \% \mathrm{CI}=1.01-2.44)$ of $-2578 \mathrm{C} / \mathrm{A}$ when compared with the 
CC genotype (Table 3). However, no statistically significant association was found between the $+936 \mathrm{C} / \mathrm{T}$ and $-460 \mathrm{~T} / \mathrm{C}$ gene polymorphisms and a risk of osteosarcoma.

\begin{tabular}{|c|c|c|c|c|c|c|}
\hline Variable & Patients & $\%$ & Controls & $\%$ & $\chi^{2}$ test & P value \\
\hline \multicolumn{7}{|l|}{ Age (years) } \\
\hline$<20$ & 82 & 45.05 & 86 & 47.25 & & \\
\hline$\geq 20$ & 100 & 54.95 & 96 & 52.75 & 0.18 & 0.67 \\
\hline \multicolumn{7}{|l|}{ Gender } \\
\hline Females & 76 & 41.76 & 76 & 41.76 & & \\
\hline Males & 106 & 58.24 & 106 & 58.24 & 0.00 & 1.00 \\
\hline \multicolumn{7}{|l|}{ Family history of cancer } \\
\hline Negative & 15 & 8.24 & 11 & 6.04 & & \\
\hline Positive & 167 & 91.76 & 171 & 93.96 & 0.66 & 0.42 \\
\hline \multicolumn{7}{|l|}{ Tumor location } \\
\hline Long tubular bones & 125 & 68.68 & & & & \\
\hline Axial skeleton & 57 & 31.32 & & & & \\
\hline \multicolumn{7}{|l|}{ Tumor metastasis } \\
\hline Negative & 119 & 65.38 & & & & \\
\hline Positive & 63 & 34.62 & & & & \\
\hline
\end{tabular}

Table 2. Genotype characteristics of $V E G F-2578 \mathrm{C} / \mathrm{A},+936 \mathrm{C} / \mathrm{T}$, and $-460 \mathrm{~T} / \mathrm{C}$ polymorphisms.

\begin{tabular}{llllcrrr}
\hline & Polymorphism & SNP & Alleles & \multicolumn{2}{c}{ MAF } & HWE (P value) in controls \\
\cline { 5 - 6 } & & & & Control group & dbSNP & \\
\hline$V E G F$ & $-2578 \mathrm{C} / \mathrm{A}$ & rs699947 & C/A & 0.3214 & 0.3245 & 0.16 \\
& $+936 \mathrm{C} / \mathrm{T}$ & $\mathrm{rs} 3025039$ & $\mathrm{C} / \mathrm{T}$ & 0.1538 & 0.1336 & $<0.05$ \\
& $-460 \mathrm{~T} / \mathrm{C}$ & $\mathrm{rs} 833061$ & $\mathrm{~T} / \mathrm{C}$ & 0.3681 & 0.3698 & 0.83 \\
\hline
\end{tabular}

$\mathrm{MAF}=$ minor allele frequencies; HWE $=$ Hardy-Weinberg equilibrium; SNP $=$ single nucleotide polymorphism.

\begin{tabular}{|c|c|c|c|c|c|c|c|}
\hline SNPs & Genotype & Osteosarcoma group & $\%$ & Control group & $\%$ & OR $(95 \% \mathrm{CI})^{1}$ & $P$ value \\
\hline \multirow[t]{4}{*}{$-2578 \mathrm{C} / \mathrm{A}$} & $\mathrm{CC}$ & 68 & 37.36 & 88 & 48.35 & 1.0 (Ref.) & - \\
\hline & $\mathrm{CA}$ & 79 & 43.41 & 71 & 39.01 & $1.44(0.90-2.32)$ & 0.11 \\
\hline & AA & 35 & 19.23 & 23 & 12.64 & $1.97(1.02-3.83)$ & 0.03 \\
\hline & $\mathrm{CA}+\mathrm{AA}$ & 114 & 62.64 & 94 & 51.65 & $1.57(1.01-2.44)$ & 0.03 \\
\hline \multirow[t]{4}{*}{$+936 \mathrm{C} / \mathrm{T}$} & $\mathrm{CC}$ & 128 & 70.33 & 138 & 75.82 & 1.0 (Ref.) & - \\
\hline & $\mathrm{CT}$ & 35 & 19.23 & 32 & 17.58 & $1.18(0.67-2.09)$ & 0.55 \\
\hline & TT & 19 & 10.44 & 12 & 6.59 & $1.71(0.75-4.01)$ & 0.17 \\
\hline & $\mathrm{CT}+\mathrm{TT}$ & 54 & 29.67 & 44 & 24.18 & $1.32(0.81-2.17)$ & 0.24 \\
\hline \multirow[t]{4}{*}{$-460 \mathrm{~T} / \mathrm{C}$} & $\mathrm{TT}$ & 65 & 35.71 & 72 & 39.56 & 1.0 (Ref.) & - \\
\hline & $\mathrm{TC}$ & 91 & 50.00 & 86 & 47.25 & $1.17(0.73-1.88)$ & 0.49 \\
\hline & $\mathrm{CC}$ & 26 & 14.29 & 24 & 13.19 & $1.20(0.60-2.42)$ & 0.58 \\
\hline & $\mathrm{TC}+\mathrm{CC}$ & 117 & 64.29 & 110 & 60.44 & $1.18(0.75-1.84)$ & 0.45 \\
\hline
\end{tabular}

${ }^{1}$ Adjusted for age and gender. $\mathrm{SNP}=$ single nucleotide polymorphism.

\section{DISCUSSION}

Certain genetic and environmental factors, which cause DNA damage, have been reported to have a role in the development of osteosarcoma (Jia et al., 2013; He et al., 2013, 2014), and the $V E G F$ gene was considered as one of the potential genetic factors in previous 
studies (Tie et al., 2014; Wang et al., 2014). The present study investigated the association between $V E G F$ genetic polymorphisms and the risk of osteosarcoma in a Chinese population, and our results suggested that the AA and $\mathrm{CA}+\mathrm{AA}$ genotypes of $V E G F-2578 \mathrm{C} / \mathrm{A}$ were statistically correlated with an increased risk of osteosarcoma.

It is well known that angiogenesis plays an important role in the development and metastasis of cancers, and VEGF is a critical factor in angiogenesis and plays important roles in promoting endothelial cell proliferation and in modifying the extracellular matrix in blood vessels (Roy et al., 2006; Kushner and Bautch, 2013). Previous studies have reported that high expression levels of VEGF are found in several kinds of solid tumors, and correlate with the promotion of microvessel density in tumor tissues (Ferrara, 2002). Epidemiologic studies have investigated the role of $V E G F$ gene polymorphisms in the susceptibility to solid tumors such as breast, lung, colorectal, gastric, and prostate cancers (Zhou et al., 2011; Maeda et al., 2013; Chen et al., 2014; Kapahi et al., 2014; Jannuzzi et al., 2015). Kapahi et al. (2014) conducted a study to evaluate the association of seven $V E G F$ gene polymorphisms with the risk of breast cancer, and they found that the $V E G F-152 \mathrm{G} / \mathrm{A}$ and $-116 \mathrm{G} / \mathrm{A}$ polymorphisms significantly increased the risk of breast cancer, and that the $V E G F-165 \mathrm{C} / \mathrm{T}$ and $-141 \mathrm{~A} / \mathrm{C}$ gene polymorphisms were correlated with a decreased risk of cancer. Maeda et al. (2013) conducted a study in a Chinese population, and reported that the $V E G F-460 \mathrm{~T} / \mathrm{C}$ polymorphism could influence tumor angiogenesis in nonsmall cell lung cancer. Jannuzzi et al. (2015) investigated the roles of the VEGF -2578A/C, $+936 \mathrm{C} / \mathrm{T}$, and $-460 \mathrm{C} / \mathrm{T}$ gene polymorphisms in modifying the susceptibility to colorectal cancer. Zhou et al. (2011) suggested that the $V E G F+1612 \mathrm{G} / \mathrm{A}$ gene polymorphism was correlated with an increased risk of gastric cancer. However, Chen et al. (2014) did not find a significant association between three $V E G F$ gene polymorphisms and prostate cancer risk. Overall, the results of these studies have been inconsistent. The discrepancies between these results might be caused by differences in the study populations, types of tumors analyzed, and the sample sizes.

Only two previous studies have reported associations between VEGF gene polymorphisms and the risk of osteosarcoma (Tie et al., 2014; Wang et al., 2014). Tie et al. (2014) assessed whether five common SNPs could affect the risk of osteosarcoma in a Chinese population, and they suggested that the $V E G F-2578 \mathrm{C} / \mathrm{A}$ and $-634 \mathrm{G} / \mathrm{C}$ polymorphisms might influence the development of osteosarcoma. Wang et al. (2014) examined the potential role of three common SNPs in the VEGF gene in the susceptibility to osteosarcoma, and they found that the $\mathrm{C}$ allele of the $-634 \mathrm{G} / \mathrm{C}$ variant was related to osteosarcoma susceptibility in a Chinese population. Therefore, further studies are greatly needed to confirm these associations.

In conclusion, our study showed that the $\mathrm{AA}$ and $\mathrm{CA}+\mathrm{AA}$ genotypes of the $V E G F$ $-2578 \mathrm{C} / \mathrm{A}$ SNP might modify the risk of osteosarcoma in a Chinese population. Furthermore, our study suggests the importance of angiogenic growth factors in the etiology of osteosarcoma.

\section{Conflicts of interest}

The authors declare no conflict of interest.

\section{REFERENCES}

Akiri G, Nahari D, Finkelstein Y, Le SY, et al. (1998). Regulation of vascular endothelial growth factor (VEGF) expression is mediated by internal initiation of translation and alternative initiation of transcription. Oncogene 17: 227-236.

Berger M, Muraro M, Fagioli F and Ferrari S (2008). Osteosarcoma derived from donor stem cells carrying the Norrie's disease gene. New Engl. J. Med. 359: 2502-2504. 
Bovée JV and Hogendoorn PC (2010). Molecular pathology of sarcomas: Concepts and clinical implications. Virchows Arch. 456: 193-199.

Chen GQ, Luo JB, Wang GZ and Ding JE (2014). Assessment of the associations between three VEGF polymorphisms and risk of prostate cancer. Tumour Biol. 35: 1875-1879.

de Alava E (2007). Molecular pathology in sarcomas. Clin. Transl. Oncol. 9: 130-144.

Ferrara N (2002). VEGF and the quest for tumour angiogenesis factors. Nat. Rev. Cancer 2: 795-803.

Hanahan D and Folkman J (1996). Patterns and emerging mechanisms of the angiogenic switch during tumorigenesis. Cell 86: 353-364.

He ML, Wu Y, Zhao JM, Wang Z, et al. (2013). PIK3CA and AKT gene polymorphisms in susceptibility to osteosarcoma in a Chinese population. Asian Pac. J. Cancer Prev. 14: 5117-5122.

He M, Wang Z, Zhao J, Chen Y, et al. (2014). Collal polymorphism is associated with risks of osteosarcoma susceptibility and death. Tumour Biol. 35: 1297-1305.

Jannuzzi AT, Özhan G, Yanar HT and Alpertunga B (2015). VEGF gene polymorphisms and susceptibility to colorectal cancer. Genet. Test Mol. Biomarkers 19: 133-137.

Jia J, Tian Q, Liu Y, Shao ZW, et al. (2013). Interactive effect of bisphenol A (BPA) exposure with -22G/C polymorphism in LOX gene on the risk of osteosarcoma. Asian Pac. J. Cancer Prev. 14: 3805-3808.

Kapahi R, Guleria K, Sambyal V, Manjari M, et al. (2014). Vascular endothelial growth factor (VEGF) gene polymorphisms and breast cancer risk in Punjabi population from North West India. Tumour Biol. 35: 11171-11181.

Kushner EJ and Bautch VL (2013). Building blood vessels in development and disease. Curr. Opin. Hematol. 20: 231-236.

Maeda A, Nakata M, Yasuda K, Yukawa T, et al. (2013). Influence of vascular endothelial growth factor single nucleotide polymorphisms on non-small cell lung cancer tumor angiogenesis. Oncol. Rep. 29: 39-44.

Mariani BM, Trarbach EB, Ribeiro TC, Pereira MA, et al. (2012). Genotype analysis of the human endostatin variant p.D104N in benign and malignant adrenocortical tumors. Clinics 67: 95-98.

Mirabello L, Troisi RJ and Savage SA (2009). Osteosarcoma incidence and survival rates from 1973 to 2004: data from the Surveillance, Epidemiology, and End Results Program. Cancer 115: 1531-1543.

Nakamura Y, Yasuoka H, Tsujimoto M, Imabun S, et al. (2005). Lymph vessel density correlates with nodal status, VEGF-C expression, and prognosis in breast cancer. Breast Cancer Res. Treat. 91: 125-132.

Osuna D and de Alava E (2009). Molecular pathology of sarcomas. Rev. Recent Clin. Trials 4: 12-26.

Ottaviani G and Jaffe N (2009). The epidemiology of osteosarcoma. Cancer Treat. Res. 152: 3-13.

Picci P (2007). Osteosarcoma (osteogenic sarcoma). Orphanet J. Rare Dis. 2: 6.

Powers M, Zhang W, Lopez-Terrada D, Czerniak BA, et al. (2010). The molecular pathology of sarcomas. Cancer Biomark. 9: 475-491.

Rinck-Junior JA, Oliveira C, Lourenço GJ, Sagarra RA, et al. (2015). Vascular endothelial growth factor (VEGF) polymorphism and increased risk of epithelial ovarian cancer. J. Cancer Res. Clin. Oncol. 141: 69-73.

Roy H, Bhardwaj S and Ylä-Herttuala S (2006). Biology of vascular endothelial growth factors. FEBS Lett. 580: 2879-2887.

Tie Z, Bai R, Zhai Z, Zhang G, et al. (2014). Single nucleotide polymorphisms in VEGF gene are associated with an increased risk of osteosarcoma. Int. J. Clin. Exp. Pathol. 7: 8143-8149.

Wang Z, Wen P, Luo X, Fang X, et al. (2014). Association of the vascular endothelial growth factor (VEGF) gene singlenucleotide polymorphisms with osteosarcoma susceptibility in a Chinese population. Tumour Biol. 35: 3605-3610.

Yang Y, Zhang X, Song D and Wei J (2014). Association between vascular endothelial growth factor gene polymorphisms and bladder cancer risk. Mol. Clin. Oncol. 2: 501-505.

Zhou Y, Li N, Zhuang W and Wu X (2011). Vascular endothelial growth factor (VEGF) gene polymorphisms and gastric cancer risk in a Chinese Han population. Mol. Carcinog. 50: 184-188. 